\title{
ANALISIS PENGUKURAN TINGKAT KEPERCAYAAN PELANGGAN DAN DAMPAKNYA PADA CITRA PLN BRIGHT BATAM
}

\author{
Renniwaty Siringoringo, Putu Hari Kurniawan \\ Universitas Putera Batam \\ e-mail: renni.ringo@gmail.com
}

\begin{abstract}
Innovative service quality, basically take form reputable technology information which the activity is create the "recharge electricity program" that have objection to effectivity and make it easier to operate. But its positivelly response by batam citizen, the aim of this research is to measures the customer value how far the relationship mediated with image corporate. This research is evaluated to measuring how much level of public trust rendered against his visit for program conducted by pln bright batam as indicated by variable the value of customers and its implications on the image of state-owned electricity company pln was bright batam as a public company. How ever the variable is implicate for further study to increasing the image position PT PLN bright Batam as a public service corporation. The population research is the customer electricity prepaid households across seven district in Batam which ones with samples from 200 respondents and engineering the sample collection using proportional. sampling techniquesThe research is explanatory survey to analyze how big the influence and the relations among a variable whose, customers confidence in image of companies. This object of study is a customer of the recharge electricity take from 200 household responden in 7 district in Batam. This research used Structure Equation Model (SEM) as model analysis which for operate data mining used Lisrel 8.3 for windows. The result showed that service quality and price have effect on trust but not on corporate image. And trust has effects on corporate image.
\end{abstract}

Keywords: Customer Value, Service Quality, Price, Trust, Corporate Image

\begin{abstract}
Abstrak
Inovasi layanan berbasis teknologi informasi yang dilakukan oleh PT PLN Bright Batam dengan menciptakan program listrik pra bayar bertujuan untuk mengefektifkan dan mempermudah pelanggan dalam mengakses dan mengatur penggunaan listrik. Namun inovasi tersebut belum semua direspon positif oleh masyarakat Batam. Tujuan dari penelitian ini adalah untuk mengukur seberapa besar tingkat kepercayaan masyarakat yang diberikan terhadap program listrik pra bayar yang dilakukan oleh PT PLN Bright Batam yang diukur oleh variabel nilai pelanggan, kualitas layanan dan tarif/harga listrik dan implikasinya terhadap citra PT PLN Bright Batam sebagai perusahaan publik. Populasi penelitian adalah pelanggan listrik prabayar rumah tangga kota Batam yang tersebar di tujuh (7) kecamatan dengan sampel sebanyak 200 responden dan teknik pengambilan sampel dengan menggunakan teknik proportional sampling. Penelitian ini merupakan explanatory survey yakni untuk menganalisis seberapa besar pengaruh dan hubungan antara variabel nilai pelanggan, kualitas layanan dan tarif/harga terhadap kepercayaan serta dampaknya terhadap citra perusahaan. Alat analisisnya menggunakan analisis Structural Equation Model (SEM) dengan alat bantu program Lisrel for Windows versi 8.3. Hasil penelitian diperoleh bahwa variabel nilai pelanggan tidak berpengaruh terhadap kepercayaan pelanggan dan citra perusahaan. Kualitas layanan berpengaruh positif terhadap kepercayaan pelanggan namun tidak berpengaruh terhadap citra perusahaan. Sedangkan variabel harga/tarif berpengaruh positif dan signifikan terhadap kepercayaan pelanggan dan tidak berpengaruh terhadap citra perusahaan. Dan variabel kepercayaan berpengaruh positif dan signifikan terhadap citra perusahaan.
\end{abstract}

Kata Kunci : Nilai Pelanggan, Kualitas Layanan, Tarif, Kepercayaan, Citra Perusahaan 


\section{PENDAHULUAN}

Perubahan teknologi informasi yang berkembang cepat, mengharuskan berbagai perusahaan dapat memberikan solusi yang tepat dan cepat sesuai dengan kebutuhan/keinginan pelanggan, sehingga pelanggan puas dan akan menjadi pelanggan yang loyal. Demikian halnya dengan PT PLN (Persero) sebagai perusahaan publik yang bergerak dibidang pendistribusian /penjualan energi listrik, dalam melayani masyarakat dan dalam proses meraih keuntungan dari usahanya tidak lagi mengandalkan pada volume penjualan saja, tetapi harus berorientasi pada long term satisfaction.

PT B'right PLN Batam merupakan anak perusahaan PT PLN (Persero), yang berperan sebagai penyuplai tenaga listrik utama di wilayah Kota Batam, Rempang dan Galang. PT B'right PLN Batam bertujuan untuk meningkatkan kesejahteraan masyarakat, mendorong peningkatan ekonomi, meningkatkan kapasitas pembangkit, keandalan sistem dan peningkatan pelayanan kepada pelanggan.

Sehubungan dengan meningkatnya permintaan listrik akibat dari berkembangnya pertumbuhan jumlah penduduk serta pertumbuhan ekonomi maka PT B'right PLN Batam terus melakukan inovasi sesuai dengan perkembangan dan tuntutan pasar/pelanggan seperti menggunakan strategi fuel mix untuk produksi tenaga listrik serta mengeluarkan program listrik Pintar atau yang dikenal dengan listrik prabayar.

Listrik Prabayar merupakan salah satu inovasi yang berbasis teknologi informasi, yang bertujuan untuk meningkatkan pelayanan dan mengefektifkan pelanggan dalam hal menggunakan dan mendapatkan energi listrik. Listrik prabayar muncul karena kelemahan dari listrik pascabayar, seperti kesalahan membaca meteran, tagihan yang tidak sesuai dengan penggunaan, tunggakan rekening (denda keterlambatan) dan pemutusan listrik, yang berdampak buruk bagi pelanggan dan juga PT PLN sendiri. Dari sisi pelanggan, program Listrik Pra Bayar membantu pelanggan untuk mengatur dan mengendalikan penggunaan listrik sendiri, sehingga masyarakat dapat berhemat menggunakan listrik. Penghematan listrik berkontribusi terhadap banyaknya cadangan listrik yang bisa disimpan, sehingga semakin banyak penduduk Indonesia yang bisa menikmati energi listrik. Listrik pra bayar tidak memiliki biaya keterlambatan dan biaya beban bulanan dan masyarakat dapat membeli dan mengisi sendiri token listrik yang akan digunakan. Hal ini untuk menghindari unsur ketidakpercayaan pelanggan terhadap sistem pasca bayar yaitu kesalahan petugas dalam membaca meteran listrik (human error).

Penggunaan listrik di kota Batam masih didominasi oleh sektor rumah tangga yakni sebanyak 39\% dari total keseluruhan penggunaan energi listrik di Batam. Sedangkan sektor industri dan bisnis menggunakan listrik 55\% dengan rincian sektor industri menggunakan 23\% dan sektor bisnis 32\%. Dari $39 \%$ pengguna listrik golongan rumah tangga, pelanggan pasca bayar sebanyak 29\% dan pelanggan pra bayar hanya 10\% (www.plnbatam.com). Jumlah ini masih jauh dari target PT B'right Batam, dimana PT PLN mengharapkan 50\% dari golongan sektor rumah tangga sudah menggunakan listrik prabayar.

Pada awal munculnya listrik prabayar di Batam yaitu tahun 2010 jumlah permintaan dari tahun ke tahun cukup tinggi, sampai pada tahun 2015 tingkat total Penjualan Tenaga Listrik sebesar 2.039.244 MWh, meningkat 2,75\% dibandingkan tahun 2014 sebesar $1.984 .749 \mathrm{MWh}$, dengan pencapaian 86,19\% dari target RKAP. Peningkatan tersebut terutama disebabkan oleh penambahan pelanggan baru yang mencapai $5,78 \%$ atau sebesar 15.522 khususnya pada golongan tarif multiguna akibat dari adanya layanan permohonan migrasi pelanggan dari layanan regular ke prabayar. Namun pada akhir tahun 2016 dan memasuki tahun 2017 jumlah permintaan pemasangan listrik prabayar mengalami penurunan (www.plnbatam.com).

Permasalahan yang terjadi saat ini di kota Batam adalah banyak pelanggan prabayar yang mengeluhkan, pada saat terjadi pemadaman listrik nilai kwh listrik (token) saldonya menjadi nol setelah pemadaman, sedangkan pada saat sebelum pemadaman saldo masih ada. Hal ini membuat banyak pelanggan beralih kembali ke sistem pasca bayar. Selain itu kebijakan kenaikan harga/tarif listrik yang 
resmi diberlakukan oleh PT PLN Bright Batam bulan Maret 2017 juga turut menambah keluhan masyarakat. Dengan keluarnya Peraturan Gubernur (Pergub), maka Bright PLN Batam memberlakukan tarif baru tahap pertama untuk beberapa golongan diatas, R1/1300 VA dari Rp 930.74,-/Kwh tarif baru menjadi Rp 1.210,-/Kwh, untuk R1/2200 VA dari $\mathrm{Rp} 970.01,-/$ Kwh tarif baru menjadi Rp 1.261/Kwh,diatas 2200VA dari Rp 1.436,-/Kwh tarif baru menjadi Rp 1.508,-/Kwh. Saat ini kebutuhan listrik golongan rumah tangga lebih besar dan terus tumbuh dari tahun ketahun melebihi kebutuhan listrik golongan industri. Hal inilah yang menjadi salah satu pertimbangan mengapa perlu dilakukan penyesuaian tarif (www.plnbatam.com).

Kenaikan tarif listrik dimasa ekonomi Batam yang sulit saat ini membuat masyarakat mengeluh, ditambah dengan kualitas layanan listrik prabayar yang mulai menurun, membuat masyarakat kurang percaya terhadap PT Bright PLN Batam. Ketidakpercayaan masyarakat terhadap PT Bright PLN Batam, dapat merusak citra perusahaan, sebagai perusahaan publik (Suroyo, 2015).

(Suharto, 2012) dalam penelitian empirisnya menemukan bahwa untuk menciptakan kepercayaan dan kepuasan pelanggan, perusahaan harus dapat meningkatkan nilai pelanggan (customer value). Monroe (1990), mengemukan bahwa nilai pelanggan adalah tradeoff antara persepsi pelanggan atas kualitas atau manfaat produk dan pengorbanan yang dilakukan lewat harga yang dibayarkan. Nilai pelanggan dapat diciptakan melalui kualitas pelayanan yang diberikan perusahaan kepada para pelanggannya. Semakin baik kualitas pelayanan, akan semakin tinggi pula nilai pelanggan terhadap perusahaan tersebut (Tjiptono, 2014: 308).

Kualitas Pelayanan didefinisikan sebagai keseluruhan gabungan karakteristik yang dihasilkan dari pemasaran rekayasa produksi dan pemeliharaan yang membuat produk dan jasa tersebut dapat digunakan untuk memenuhi harapan pelanggan atau konsumen (Wijaya, 2011: 11). Pentingnya pelayanan yang baik adalah untuk menumbuhkan kepercayaan pelanggan. Masalah pelayanan pelanggan menjadi sangat krusial dalam hal ini, untuk mengantisipasi rendahnya kepuasan yang masih dirasakan oleh konsumen PLN Bright Batam.

Harga/Tarif adalah sejumlah uang yang ditukarkan untuk memperoleh suatu produk, atau secara umum harga adalah uang yang dikeluarkan oleh pelanggan untuk mendapatkan manfaat dari penggunaan produk (Kotler, 2007). Saat menetapkan harga, perusahaan harus mempertimbangkan faktor-faktor lain seperti lingkungan eksternal. Kondisi ekonomi memiliki pengaruh yang kuat pada strategi harga perusahaan. Hasil kajian empiris (Rivai \& Wahyudi, 2017) menyatakan bahwa faktor-faktor ekonomi seperti inflasi, resesi dan tingkat bunga mempengaruhi keputusan penetapan harga, karena faktor-faktor tersebut mempengaruhi terhadap biaya produksi produk dan persepsi konsumen terhadap nilai dan harga produk.

PT B'right PLN Batam sebagai perusahaan publik anak perusahaan PT PLN (Persero) yang menjalankan usaha distribusi energi listrik ke pelanggan dituntut untuk menjaga citra perusahaan (corporate image), jangan sampai terjadi implikasi negatif yang dapat mengurangi kepercayaan pelanggan kepada perusahaan, yang akhirnya akan mengurangi citra perusahaan dimata pelanggannya. Sebagai perusahaan yang sekaligus menyediakan produk/jasa, PT. PLN (Persero) harus dapat memberikan kualitas pelayanan yang prima, yaitu pelayanan yang sangat baik dan melampaui harapan pelanggan sehingga dapat memuaskan para pelanggannya secara lebih baik, yang pada gilirannya dapat menumbuhkan loyalitas pelanggan (Tjiptono, 2014: 309). 


\section{METODE}

Jenis penelitian yang digunakan adalah deskriptif dan verifikatif, sehingga terdapat dua metode survey yang diterapkan yaitu descriptive survey dan explanatory survey. Instrumen yang digunakan untuk mengumpulkan data adalah daftar pertanyaan berupa kuesioner yang akan disebarkan kepada pelanggan listrik prabayar PLN Bright di tujuh (7) kecamatan di wilayah Batam.

Teknik analisis data dalam penelitian ini adalah dengan menggunakan Structural Equation Modeling (SEM). SEM adalah teknik Statistik Multivariat yang merupakan kombinasi antara analisis faktor dan analisi regresi (korelasi), yang bertujuan untuk menguji hubungan-hubungan antara variabel yang ada pada sebuah model, baik itu antar indikator dengan konstruknya, ataupun hubungan antar konstruk (Santoso, 2011:12). Perhitungan SEM dilakukan dengan menggunakan bantuan perangkat lunak program Lisrel 8.3.

Pada penelitian ini terdapat 5 variabel laten yakni 3 exogeneous latent variabel dan 2 endogenous latent variable. Karakteristik dan batasan populasi untuk mengumpulkan data yang diperlukan dalam penelitian ini adalah Pelanggan listrik yang berorientasi pada rumah tangga sebanyak 200 responden. Teknik sampling yang digunakan dalam penelitian ini adalah Proporsional Sampling. Sesuai dengan model analisis yang telah dijelaskan di atas maka pengolahan dan analisis data dilakukan dengan menggunakan teknik Multivariat Structure Equation Model (SEM), dimana dalam pengolahan data menggunakan alat bantu analisis software Lisrel 8.8 For Windows.

\section{HASIL DAN PEMBAHASAN}

\subsection{Desriptif Responden}

Dalam penelitian ini jumlah responden yang memenuhi syarat untuk dianalisis sejumlah 200 dan jumlah seluruh variabel manifest dann yang dijadikan indikator pertanyaan adalah sebanyak 28 pertanyaan. Sedangkan rule of thumb untuk perbandingan jumlah sampel terhadap jumlah indikator adalah 1:5 (Kurniawan, Loekito, \& Solimun, 2016).

Dari hasil survei terhadap 200 responden diperoleh profil pelanggan PLN Bright Batam dalam tabel 1 sebagai berikut:

Tabel 1. Deskripsi Responden

\begin{tabular}{llll}
\hline Keterangan & & Jumlah & \multicolumn{1}{c}{$\%$} \\
\hline Alamat & Kec. Batam Kota & 57 & 28,5 \\
& Kec. Batu Aji & 34 & 17,0 \\
& Kec. Bengkong & 13 & 6,5 \\
& Kec. Lubuk Baja & 31 & 15,5 \\
& Kec. Nongsa & 13 & 6,5 \\
& Kec. Sagulung & 31 & 15,5 \\
& Kec. Sekupang & 21 & 10,5 \\
Jenis kelamin: & Pria & 85 & 42,5 \\
Pendidikan : & Wanita & 115 & 57,5 \\
& SD/SMP/SMA & 107 & 53,5 \\
Usia : & D1/D3 & 11 & 5,5 \\
& S1/S2 & 82 & 41,0 \\
& 20-30 tahun & 69 & 34,5 \\
& 31-40 tahun & 101 & 50,5 \\
\hline
\end{tabular}




\begin{tabular}{llll}
\hline \multirow{3}{*}{ Profesi : } & $>40$ tahun & 30 & 15 \\
& Bisnis/Wiraswasta & 32 & 16,0 \\
& Karyawan Swasta & 96 & 48,0 \\
& PNS/BUMN & 11 & 5,5 \\
Penghasilan : & Lainnya... & 61 & 30,5 \\
& $<$ Rp 3.000.000 & 43 & 21,5 \\
& $3.000 .000-$ & 73 & 36,5 \\
& 5.000 .000 & 70 & 35,0 \\
& $5.000 .000-$ & 14 & 7,0 \\
& 10.000 .000 & & \\
\hline & $>10.000 .000$ & & \\
\hline
\end{tabular}

Sumber : Data diolah (2018)

Untuk wilayah/alamat responden didominasi oleh penduduk dikecamatan Batam Kota sebanyak 28,5\%, karena di daerah Batam Kota banyak perumahan baru yang rata-rata menggunakan fasilitas listrik prabayar. Kategori responden dilihat dari jenis kelamin didominasi oleh wanita sebanyak 57,5\%. Dilihat dari tingkat pendidikan responden didominasi dengan tingkat pendidikan SD/SMP/SMA sebesar 53,5\%. Sedangkan untuk kategori usia responden mayoritas berada diumur 31-40 tahun yakni sebesar 50,5\%. Profesi responden didominasi karyawan swasta sebesar 48,0\%. Dan untuk penghasilan, mayoritas tingkat pendapatan responden berkisar 3.000.000,-5.000.000,- per bulan sebesar 36,5\%.

\subsection{Uji Validitas dan Reliabilitas}

Menurut (Hair, 2009) pengujian validitas adalah pengujian untuk mengetahui kemampuan indikatorindikator suatu konstruks (laten variabel) untuk mengukur konstruks tersebut secara akurat. Ada dua hal yang dilakukan dalam pengujian validitas yaitu pemeriksaan terhadap nilai " $t$ " dan pemeriksaan terhadap tingginya muatan factor standard atau $\lambda$ (Standardize loading factor).

Dari hasil pengujian dengan menggunakan program Lisrel diperoleh bahwa nilai loading factor dari variabel manifest rata-rata berada diatas nilai 0,6 dan nilai $\mathrm{t}>1.95$, kecuali untuk indikator Y1 memiliki nilai loading factor 0,38 dan t-value 0,00 dan indikator $\mathrm{Y} 7$ memiliki loading factor 0,76 namun nilai tvalue 0,00 (tidak signifikan), sehingga kedua variabel tersebut dikeluarkan (didrop) dari indikator variabel manifest. Setelah dilakukan drop terhadap kedua variabel tersebut diperoleh hasil uji validitas pada tabel 2 sebagai berikut :

Tabel 2. Hasil Uji Validitas Indikator

\begin{tabular}{|c|c|c|c|c|}
\hline \multicolumn{2}{|c|}{ Variabel } & \multirow[t]{2}{*}{ Loading Factor } & \multirow{2}{*}{$\begin{array}{l}\text { Cut } \\
\text { off }\end{array}$} & \multirow{2}{*}{$\begin{array}{c}\text { Kriteria } \\
\text { Uji }\end{array}$} \\
\hline Latent & Indikator & & & \\
\hline \multirow{4}{*}{$\begin{array}{l}\text { Nilai } \\
\text { Pelanggan }\end{array}$} & $\mathrm{X} 1$ & 0,77 & 0,5 & Valid \\
\hline & $\mathrm{X} 2$ & 0,80 & 0,5 & Valid \\
\hline & $\mathrm{X} 3$ & 0,60 & 0,5 & Valid \\
\hline & $\mathrm{X} 4$ & 0,61 & 0,5 & Valid \\
\hline \multirow{6}{*}{$\begin{array}{l}\text { Kualitas } \\
\text { Layanan }\end{array}$} & $\mathrm{X} 5$ & 0,68 & 0,5 & Valid \\
\hline & X6 & 0,63 & 0,5 & Valid \\
\hline & $\mathrm{X} 7$ & 0,64 & 0,5 & Valid \\
\hline & $\mathrm{X} 8$ & 0,78 & 0,5 & Valid \\
\hline & X9 & 0,70 & 0,5 & Valid \\
\hline & X10 & 0,70 & 0,5 & Valid \\
\hline Harga/Tarif & X11 & 0,75 & 0,5 & Valid \\
\hline
\end{tabular}




\begin{tabular}{lcccc}
\hline \multirow{5}{*}{$\begin{array}{l}\text { Kepercayaa } \\
\text { n }\end{array}$} & X12 & 0,86 & 0,5 & Valid \\
\cline { 2 - 5 } & X13 & 0,66 & 0,5 & Valid \\
\cline { 2 - 5 } & X14 & 0,63 & 0,5 & Valid \\
\cline { 2 - 5 } & Y2 & 0,81 & 0,5 & Valid \\
\cline { 2 - 5 } & Y4 & 0,79 & 0,5 & Valid \\
\cline { 2 - 5 } & Y5 & 0,79 & 0,5 & Valid \\
\cline { 2 - 5 } Citra & Y6 & 0,85 & 0,5 & Valid \\
\cline { 2 - 5 } Perusahaan & Y9 & 0,78 & 0,5 & Valid \\
\cline { 2 - 5 } & Y10 & 0,77 & 0,5 & Valid \\
\cline { 2 - 5 } & Y11 & 0,70 & 0,5 & Valid \\
\cline { 2 - 5 } & Y12 & 0,78 & 0,5 & Valid \\
\cline { 2 - 5 } & Y13 & 0,75 & 0,5 & Valid \\
\cline { 2 - 5 } & Y14 & 0,79 & 0,5 & Valid \\
\hline
\end{tabular}

Untuk pengujian reliabilitas digunakan cronbach alpha reliability. Konstruk yang dianggap reliabel adalah lebih besar dari 0,7 (Hair, 2009). Hasil uji reliabilitas penelitian ini disajikan pada tabel 3 sebagai berikut :

Tabel 3. Hasil Uji Reliabilitas

\begin{tabular}{lccl}
\hline \multicolumn{1}{c}{ Variabel } & Koef. Cronbach Alpha & Cut off & Kriteria Uji \\
\hline Nilai Pelanggan & 0,784 & 0,7 & Reliabel \\
\hline Kualitas Layanan & 0,842 & 0,7 & Reliabel \\
\hline Harga/Tarif & 0,813 & 0,7 & Reliabel \\
\hline Kepercayaan & 0,902 & 0,7 & Reliabel \\
\hline Citra Perusahaan & 0,915 & 0,7 & Reliabel \\
\hline
\end{tabular}

Dari tabel 3 menunjukkan bahwa seluruh variabel, yaitu Nilai Pelanggan, Kualitas Layanan, Harga, Kepercayaan dan Citra Perusahaan memiliki nilai reliabilitas yang lebih besar dari 0,7. Dengan demikian seluruh variabel tersebut dapat digunakan untuk pengukuran selanjutnya.

\subsection{Hasil Analisis Data}

Analisis data dengan menggunakan Structural Equation Model pada penelitian ini menggunakan sofware Lisrel8.30. Software ini digunakan untuk menghitung dan menguji keterkaitan antar variabel secara simultan sesuai dengan kerangka konseptual.

Secara khusus dalam SEM, model dispesifikasikan menjadi model pengukuran dan model struktural. Sebelum menganalisis model tersebut, perlu dilakukan uji kecocokan atau kesesuaian (goodness of fit) keseluruhan model. Hasil goodness of fit model penelitian ini ditunjukkan pada tabel 4 sebagai berikut :

Tabel 4. Uji Kesesuaian Model

\begin{tabular}{llll}
\hline $\begin{array}{l}\text { Ukuran } \\
\text { Goodness of } \\
\text { Fit }\end{array}$ & $\begin{array}{l}\text { Hasil } \\
\text { Statistik }\end{array}$ & Cut-off & Kriteria Uji \\
\hline Statistik X & & & \\
\hline P-value & 740.41 & Rendah & - \\
\hline GFI & 0,04 & $>0,05$ & $\begin{array}{l}\text { Marginal } \\
\text { Fit }\end{array}$ \\
\hline
\end{tabular}




\begin{tabular}{llll}
\hline RMSEA & 0,085 & $\leq 0,05$ & $\begin{array}{l}\text { Marginal } \\
\text { Fit }\end{array}$ \\
\hline ECVI & 4,15 & $<$ ECVI for saturated & Good Fit \\
\hline AIC & 826,15 & $<$ Independence AIC & Good Fit \\
\hline CAIC & 1092,65 & $<$ Saturated CAIC & Good Fit \\
\hline NFI & 0,94 & $>0,9$ & Good Fit \\
\hline CFI & 0,97 & $>0,9$ & Good Fit \\
\hline AGFI & 0,74 & $>0,6$ & Good Fit \\
\hline
\end{tabular}

Dari tabel 4 diatas diperoleh nilai kesesuaian model untuk nilai p-value dan RMSEA diperoleh kriteria uji Marginal fit, sedangkan untuk pengukuran GFI, ECVI, AIC, NFI, CFI dan AGFI diperoleh kriteria uji good fit. Sehingga dari beberapa kriteria pengukuran kesesuaian model telah menunjukkan fit indeks yang mencukupi, sehingga dapat disimpulkan bahwa terdapat kesesuaian antara model yang diajukan dengan data yang disajikan.

Setelah uji kesesuaian model, kemudian dilakukan uji model struktural. Kriteria pengujian model struktural yaitu dengan membandingkan nilai t-value dan t-tabel dengan tingkat kesalahan 5\% yaitu sebesar 1,95. Hasil perhitungan dengan lisrel diperoleh path diagram model struktural pada gambar 3 sebagai berikut :

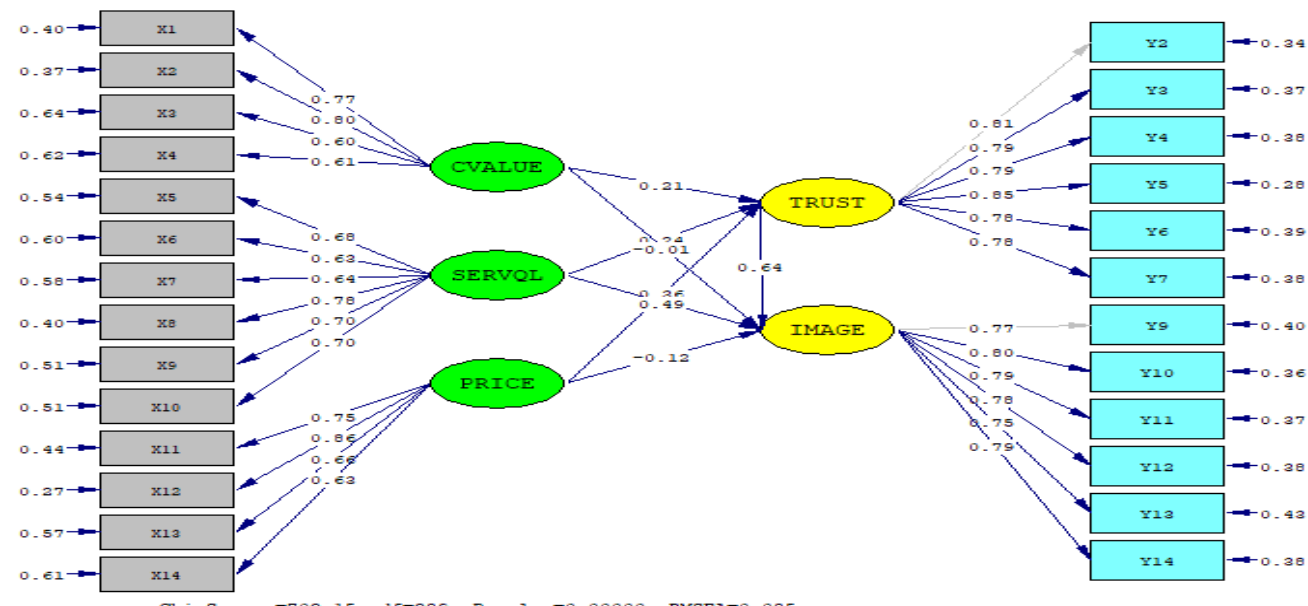

Gambar 3. Path Diagram Model Struktural

\subsection{Pengujian Hipotesis}

Berdasarkan hasil pengujian pada model struktural diperoleh persamaan struktural sebagai berikut:

1. TRUST $=0.21 *$ CVALUE $+0.24 *$ SERVQL $+0.36 *$ PRICE, Errorvar. $=0.44, \mathrm{R}^{2}=0.56$
$(0.12)$
$(0.12)$
$(0.14)$
$(0.072)$
1.72
1.96
2.49
6.15

2. IMAGE $=0.64 *$ TRUST $-0.0080 *$ CVALUE + 0.49*SERVQL - 0.12*PRICE, Errorvar $=0.13, \mathrm{R}^{2}=$ 0.87
$(0.084) \quad(0.090)$
$(0.100)$
$(0.11)$
$(0.035)$
$\begin{array}{ll}7.65 & -0.089\end{array}$
4.87
$-1.07$
3.67 
Pengujian hipotesis penelitian dilakukan dengan menguji hubungan antar variabel laten seperti persamaan dan untuk menguji hubungan antar variabel laten diperlukan Score Factor dari setiap variabel laten tersebut, perlu diperhatikan bahwa model struktural diuji secara serentak.

Berikut ini adalah hasil pengujian hipotesis:

\section{H1 Nilai pelanggan berpengaruh terhadap Kepercayaan pelanggan.}

Koefisien pengaruh nilai pelanggan terhadap kepercayaan sebesar 0,21. Namun nilai t sebesar 1,72 lebih kecil dari 1,95 (nilai kritis) sehingga hipotesis ditolak, yang berarti bahwa nilai pelanggan tidak berpengaruh secara signifikan terhadap kepercayaan pelanggan. Hasil ini sejalan dengan penelitian yang dilakukan oleh (Suharto, 2012) bahwa konsumen belum merasakan secara emosional nilai pelanggan karena program hubungan dengan pelanggan yang dilakukan oleh PT PLN belum menyentuh sampai aspek pribadi konsumen sehingga tingkat kepercayaan terhadap pelanggan masih kurang.

\section{H2 Nilai pelanggan berpengaruh terhadap Citra Perusahaan}

Koefisien pengaruh nilai pelanggan terhadap citra perusahaan bernilai negatif sebesar $(-0,008)$ dan nilai $t$ sebesar -0,089 juga lebih kecil dari nilai kritis sehingga hipotesis ditolak. Hal ini berarti nilai pelanggan tidak berpengaruh secara signifikan terhadap citra perusahaan. Hasil ini sejalan dengan hipotesis pertama, dimana hubungan yang dilakukan oleh PLN terhadap pelanggan belum sampai pada aspek emosional/pribadi pelanggan sedangkan citra perusahaan sangat berkaitan dengan aspek emosional. Perasaan ini tidak akan terjadi tanpa adanya pengalaman individu dengan suatu organisasi.

\section{H3 Kualitas Layanan terhadap Kepercayaan pelanggan.}

Koefisien pengaruh kualitas layanan terhadap kepercayaan pelanggan bernilai negatif sebesar 0,24 dan nilai t sebesar 1,96 lebih besar dari nilai kritis sehingga hipotesis diterima. Hal ini berarti kualitas layanan berpengaruh positif dan signifikan terhadap kepercayaan pelanggan. Hasil ini sejalan dengan penelitian yang dilakukan oleh (Suharto, 2012) bahwa kualitas pelayanan berpengaruh positif dan signifikan terhadap kepercayaan pelanggan.

\section{H4 Kualitas Layanan berpengaruh terhadap Citra Perusahaan}

Koefisien pengaruh kualitas layanan terhadap citra perusahaan bernilai positif sebesar 0,49 dan nilai $t$ sebesar 4,87 lebih besar dari nilai kritis sehingga hipotesis diterima. Hal ini berarti kualitas layanan berpengaruh positif dan signifikan terhadap citra perusahaan. Hasil ini sejalan dengan penelitian yang dilakukan oleh (Pramudya, Sudiro, \& Sunaryo, 2018) bahwa kualitas layanan berpengaruh positif terhadap pembentukan citra/reputasi perusahaan, terutam perusahaan publik yang memberikan pelayanan langsung kepada masyarakat umum.

\section{H5 Harga/Tarif terhadap Kepercayaan pelanggan}

Koefisien pengaruh harga/tarif terhadap kepercayaan pelanggan bernilai positif sebesar 0,36 dan nilai $t$ sebesar 2,49 lebih besar dari nilai kritis sehingga hipotesis diterima. Hal ini berarti harga/tarif berpengaruh positif dan signifikan terhadap kepercayaan pelanggan. Hasil ini sejalan dengan penelitian (Rivai \& Wahyudi, 2017) dan (Suharto, 2012). Harga/Tarif merupakan faktor yang sangat sensitif dalam hal mempengaruhi kepercayaan konsumen, terutama pada institusi pelayanan publik seperti PT PLN. Harga listrik prabayar dengan tingkat penggunaan yang dilakukan oleh konsumen sudah sesuai dengan harapan konsumen. 


\section{H6 Harga/Tarif berpengaruh terhadap Citra Perusahaan}

Koefisien pengaruh harga/tarif terhadap citra perusahaan bernilai negatif sebesar 0,12 dan nilai t sebesar -1,07 lebih kecil dari nilai kritis sehingga hipotesis ditolak. Hal ini berarti harga/tarif tidak berpengaruh terhadap citra perusahaan.

\section{H7 Kepercayaan Pelanggan berpengaruh terhadap Citra Perusahaan}

Koefisien pengaruh kepercayaan pelanggan terhadap citra perusahaan bernilai positif sebesar 0,64 dan nilai t sebesar 7,65 lebih besar dari nilai kritis sehingga hipotesis diterima. Hal ini berarti kepercayaan pelanggan berpengaruh positif dan signifikan terhadap citra perusahaan. Kepercayaan yang diberikan oleh masyarakat sebagai wujud pengalaman pribadi yang dirasakan oleh konsumen harus ditingkatkan sehingga dapat membentuk citra positif bagi perusahaan.

\section{KESIMPULAN}

Hasil penelitian ini menunjukkan bahwa nilai pelanggan yang dirasakan oleh masyarakat Batam terutama pelanggan PLN Prabayar belum menyentuh sisi emosional pelanggan yang menyebabkan kurangnya kepercayaan masyarakat, sehingga PT PLN Bright perlu mengadakan program dalam meningkatkan interkasi perusahaan dengan perusahaan seperti peningkatan dalam program CSR untuk mempererat hubungan pelanggan dengan perusahaan secara emosional. PT PLN juga perlu menjaga tarif listrik agar tetap stabil, karena listrik merupakan salah satu kebutuhan dasar konsumen semua golongan dan tingkatan.

Keterbatasan yang mungkin mempengaruhi hasil penelitian yang ingin dicapai antara lain: keterbatasan jumlah responden sehingga data tidak dapat diuji secara serentak (single step) meskipun hasil analisis yang dihasilkan akan sama tetapi diagram path yang dihasilkan tidak akan digambarkan keseluruhan model yang terdiri dari model pengukuran dan model struktural (2) keterbatasan yang melekat pada data yang diperoleh melalui kuesioner, karena perbedaan persepsi penulis dengan responden penelitian.

\section{SARAN}

Saran untuk penelitian yang akan datang adalah yang paling utama responden penelitian ini sangat homogen dimana observasi hanya dilaksanakan pada satu institusi saja,. Sebaiknya penelitian yang akan datang harus dapat mengembangkan dengan meneliti pada lingkup lembaga atau instansi yang memiliki jejaring luas dengan model bisnis lainnya. Sampel yang digunakan diharapkan diperbanyak minimal sesuai dengan rule of thumb_pada Covarian basic SEM secara umum. Dengan mengembangkan variabel dan analisa yang lebih tinggi seperti PLS atau GESCA Analysis.

\section{DAFTAR PUSTAKA}

[1].Aydin, S., \& Ozer, G. (2007). The Analysis Of Antecedents Of Customer Loyalty In The Turkish Mobile Telecommunication Market. European Journal of Marketing, 39(7/8), 910-925.

[2].Hair, J. (2009). Multivariate Data Analysis. Faculty Publications.

[3].Hasan, A. (2008). Marketing. Yogyakarta: Media Utama. 
[4].Kotler, P. (2007). Manajemen Pemasaran: Analisis Perencanaan dan Pengendalian (Bahasa Ind). Jakarta: Salemba Empat.

[5].Kotler, P., \& Keller, K. (2012). Manajemen Pemasaran (Edisi 12 J). Jakarta: Indeks.

[6].Kurniawan, A., Loekito, L., \& Solimun, S. (2016). Power Of Test Path Analysis and Partial Least Square Analysis. CAUCHY; Vol 4, No 3 (2016): CAUCHYDO - 10.18860/ca.v4i3.3593 , 4(3), 112114.

[7].Pramudya, A. K., Sudiro, A., \& Sunaryo. (2018). The Role of Customer Trust in Mediating Influence of Brand Image and Brand Awareness of The Purchase Intention In Airline Tickets Online. Journal Of Applied Management, 16(2), 224-233.

[8].Rivai, A. R., \& Wahyudi, T. A. (2017). Pengaruh Persepsi Kualitas , Citra Merek , Persepsi Harga terhadap Loyalitas Pelanggan dengan Kepercayaan dan Kepuasan Pelanggan Sebagai Variabel Mediasi. Jurnal Bisnis Dan Komunikasi, 4(1), 29-37.

[9].Sangadji, E. ., \& Sopiah. (2013). Perilaku Konsumen. Yogyakarta: Penerbit Andi.

[10].Santoso, S. (2011). Buku Latihan SPSS Parametrik. Jakarta: PT Eleks Media Komputindo.

[11].Saputra, Trio, Utami, Bunga, \& Sufi, Wasiah. (2018). Pengaruh Persepsi Mahasiswa Terhadap Kualitas Pelayanan Pegawai Dibagian Administrasi Fakultas Ilmu Administrasi Universitas Lancang Kuning. Jurnal Niara, 11(1), 6-16. Https://Doi.Org/10.31849/Nia.V11i1.1520

[12].Suharto. (2012). Pengaruh Service Quality terhadap Loyalitas Dimediasi Customer Value dan Customer Trust. Jurnal Aplikasi Manajemen, 10(1), 199-215.

[13].Suroyo, F. (2015). Pengaruh Pelayanan Berbasis Teknologi Informasi Listrik Prabayar dan Kerelasian Pelanggan terhadap Kepercayaan Pelanggan dan Dampaknya pada Citra Perusahaan The Influence of Service Based on Information Technology Electric Prepaid and Customers Relationsh. Jurnal Bisnis \& Manajemen, XVI(1), 13-21.

[14].Tjiptono. (2014). Pemasaran Jasa: Prinsip, Penerapan dan Penelitian. Yogyakarta: Penerbit Andi.

[15].Wijaya, T. (2011). Manajemen Kualitas Jasa. Jakarta: Penerbit Indeks. 